\title{
Considerations of a physician on a lecture on the Trans-human
}

\author{
Florindo Pirone \\ Dirigente f.r. Ospedale Sandro Pertini, Roma, Italy
}

\begin{abstract}
The letter offers a clear presentation on the evolution of the so-called Trans-human, through brief quotes from intellectuals who have highlighted some of its fundamental characteristics and main ideas. It expresses the expectations and concerns of a physician facing these future prospects.
\end{abstract}

\section{Considerations on the Trans-human}

I have recently attended a lecture ${ }^{1}$ on the so-called Trans-human, on the emerging biological and information technologies which are allegedly capable of transforming man physically and mentally into something radically new, the hybrid.

The lecture offered a clear presentation on the evolution of this concept, through brief quotes from intellectuals who have highlighted some of its fundamental characteristics and whose main ideas, in my opinion, can be summarized as follows: i) It is rather a fear that, in the end, biotechnology will cause us in some way to lose our humanity-that is, some essential quality that has always underpinned our sense of who we are and where we are going, despite all of the evident changes that have taken place in the human condition through the course of history. (Francis Fukuyama); ${ }^{2}$ ii) Nature could not have taken a greater risk than giving birth to man. [...]. Through man, nature has destroyed itself. (Hans Jonas); ${ }^{3}$ iii) Human evolution is nearly a finished chapter in the history of life. That does not mean the evolution of intelligence has ended on the Earth. We can expect that a new species will arise out

Correspondence: Florindo Pirone, Dirigente f.r. Ospedale Sandro Pertini, Roma, Italy.

E-mail: florindo.pirone@virgilio.it

Key words: Trans-human; medicine.

Received for publication: 7 June 2018.

Revision received: 8 January 2019.

Accepted for publication: 16 January 2019

This work is licensed under a Creative Commons Attribution NonCommercial 4.0 License (CC BY-NC 4.0).

(C) Copyright F. Pirone, 2019

Licensee PAGEPress, Italy

Italian Journal of Medicine 2019; 13:132-134

doi:10.4081/itjm.2019.1052 of man, surpassing his achievements as he has surpassed those of his predecessor Homo erectus. The new kind of intelligent life is more likely to be made of silicon. (Robert Jastrow). ${ }^{4}$

In these three passages a storyline is retraceable and begins with the human, moves onto the substantial changes in that undefined essential quality and, through the technological transformations (genetic, artificial intelligence, robotics, nanotechnologies...), finally reaches a new posthuman entity.

The following considerations on these three aspects express the expectations and concerns of a physician facing these perspectives. Although these topics do not belong directly to the medical realm, the latter is undoubtedly affected by them, as on the one hand, many of the proposals stand as cures in their own right or as empowerment of physical-psychological abilities, and on the other hand, as medicine, by its very nature, has always had to face both objective (technical-scientific) and subjective (ethical-moral) human aspects.

While browsing the literature on Trans-human on the Internet, it is possible to find an incredibly long list of entries, and looking for that human undefined quality in that same fashion does not produce meaningful results.

Trying to restrict in a single definition the essence of human condition is not just an extremely and complex endeavor, it is simply impossible. From the Bible narrations to the theories of Einstein, Shakespearian tragedies to Beethoven symphonies, the horrors of Hitler to the lyricism of Michelangelo's Pietà, all these threads and many more infinite ones are all connected to our humanity. As Boris Pasternak once wrote: Life always spills over the rim of every cup. ${ }^{5}$

Contrary to what the upholders of this imminent radical transformation believe, this impossibility also depends on the fact that humans have always been in constant change both in their interactions with the world, and amongst and within themselves. The image of a human existence with fixed characteristics once and for all does not reflect the truth. Both the biolog- 
ical and cultural evolutions have accompanied us since the beginning.

However, it is possible to compare the First Article of the Universal Declaration of Human Rights (1948): All human beings are born free and equal in dignity and rights. They are endowed with reason and conscience and should act towards one another in a spirit of brotherhood with the First Article of the Declaration of Trans-humanists (2009): Humanity stands to be profoundly affected by science and technology in the future. We envision the possibility of broadening human potential by overcoming aging, cognitive shortcomings, involuntary suffering, and our confinement to planet Earth. ${ }^{6}$

The intellectual and emotional resonances of the two Declarations, respectively, are straightforward and deeply different. The second promises cures to diseases and empowerment of existing human capabilities, leaving doubts as to what could be the emerging ones. No words are instead spoken about those ideals considered typical of the human beings such as freedom and dignity, which are denied or - being non-quantifiable and, as such, lacking of objectivity - are not taken into consideration by the reductionism which is specifically dominant in the technical and scientific culture. Finally, it avoids law-related recommendations including solidarity, perhaps substituted by an implicit undeniable appreciation for ruthless competition.

Jonas' warning raises two considerations that are apparently conflicting. On the one hand, it makes us ponder on the many promises of the general and relentless progress, which is in conflict with issues such as those presented by the possible catastrophe due to climate changes. ${ }^{7}$ This critical consideration is represented poetically by Leopardi's timeless verse: Dipinte in queste rive/Son dell'umana gente/Le magnifiche sorti e progressive [The magnificent and progressive fate of the human race is depicted in this place].

On the other hand, it brings out the anthropocentrism implicit in the claims to glorify or destroy $n a$ ture. However, it is indeed thanks to all the knowledge gained from science and technology that we know that man is one of the several living beings, placed on a planet that revolves around one out of million stars in our galaxy, which in turn is one out of billions of galaxies in our universe. ${ }^{8}$ Claiming to be able to radically affect the whole of nature it is only a sign of the infinite human imagination.

The last quote by Jastrow poses deep questions on the proposed future scenarios and on the topics on which these prospects are based. It echoes, in a way and under another form, the thesis by Fukuyama in his 'The end of history and the last man' expressed in 1989. His conceptual premises are multiple and all debatable. The theses that human history and evolution have ended have no empirical evidence. ${ }^{9,10}$
The possibility to use even more sophisticated technology to cure diseases and dysfunctions is a wellestablished medical practice: current joints prosthesis, cardiac pacemakers or neuro-microchips for Parkinson stand as well accepted and common examples.

Completely different is the aim to intervene on the genetic makeup or to introduce microchips in the brain to empower and broaden human capabilities considered at a standard level: a goal that even if not calling on the notorious eugenics, it still brings about complex questions on nature, from a sociological, economic and ethical point of view. (On which basis will the qualities to be increased be decided? Who will benefit from this opportunity? Will an invasive control on body and mind arise?). Until now physicians have intervened to correct defects and curb the suffering deriving from the break in the existing biological balances: this new approach instead would lead to abruptly unsettle the harmony established over a long period of time, with the risk of obtaining disastrous and unexpected results. If the latter happened, it would be the case as expressed by physicist Eugene Wigner on the miraculous harmony of mathematics with physics: ... a wonderful gift which we neither understand nor deserve. ${ }^{11}$

The expectation that a new species able to overtake the previous ones would develop entails value judgements that are typical of human subjectivity, and echoes the ancient mythology of omniscience and immortality (not to mention the promotion of financial interests of some industries).

These short and incomplete considerations on the Trans-human, which should suggest images of an imminent post-human future, all evoke instead the title of the famous book by Friedrich Nietzsche Human, all too human as well as Pascal's thought, which should remind us about our peculiarities and limits. Man is but a reed, the feeblest thing in nature; but he is a thinking reed. The entire universe need not arm itself to crush him. A vapour, a drop of water suffices to kill him. But, if the universe were to crush him, man would still be more noble than that which killed him, because he knows that he dies and the advantage which the universe has over him; the universe knows nothing of this. All our dignity consists, then, in thought. By it we must elevate ourselves, and not by space and time which we cannot fill. Let us endeavour, then, to think well; this is the principle of morality. ${ }^{12}$

\section{References}

1. Longo GO. Uomo e tecnologia, verso il post-umano. Roma: Palazzo delle Esposizioni; 3 maggio 2018.

2. Fukuyama F. Our posthuman future: consequences of the biotechnology revolution. London: Profile Books Ltd; 2002. 
3. Jonas H. Das Prinzip Verantwortung: Versuch einer Ethik für die technologische Zivilisation. Frankfurt/M.: 1979. Nuova edizione: Suhrkamp Taschenbuch, 1984. [Italian transl.: Il principio di responsabilità. Un'etica per la civiltà tecnologica, curato da P. P. Portinaro. Milano: Biblioteca Einaudi; 2002.

4. Jastrow R. Toward an intelligence beyond man's. Time, February 20, 1978;111:59. Available from: http://content. time.com/time/magazine/article/0,9171,948024,00.html

5. Lerda F. Intelligenza umana e intelligenza artificiale. Est modus in rebus. Catanzaro: Rubettino Editore; 2002. pp. 54 [Italian edition].

6. Transumanisti Italiani. La Dichiarazione Transumanista; 2009. Available from: http://www.transumanisti.org/ index.php?option $=$ com_content\&view $=$ article \&id $=27 \&$ It emid $=50$

7. Simon-Lewis A. What is climate change? The definition, causes and effects; 6 February 2018. Available from: http://www.wired.co.uk/article/what-is-climate-changedefinition-causes-effects
8. Greco P. L'origine dell'universo. Roma: Editori Riuniti; 2017.

9. Pennisi E. Humans are still evolving - and we can watch it happen; 17 May 2016. Available from: http://www.sciencemag.org/news/2016/05/humans-are-still-evolvingand-we-can-watch-it-happen

10. Ratner P. Researchers find evidence that human evolution is still actively happening; 9 September 2017. Available from: http://bigthink.com/paul-ratner/scientistsfind-evidence-of-human-evolution-still-actively-happening

11. Wigner E. The unreasonable effectiveness of mathematics in the natural sciences; Communications in Pure and Applied Mathematics, February 1960, final sentence. Available from: https://www.dartmouth.edu/ matc/ MathDrama/reading/Wigner.html

12. Pascal B. Les Pensées, 347, Gutenberg Project. Available from: https://michelinewalker.com/2014/04/19/ blaise-pascals-roseau-pensant/ 